\title{
Climatic conditions during migration affect population size and arrival dates in an Afro-Palearctic migrant
}

Running title: Climate and demography in Sand Martins

THOMAS O. MONDAIN-MONVAL, ${ }^{1 *}$ KEVIN BRIGGS, ${ }^{2}$ JOHN WILSON ${ }^{3} \&$ STUART P. SHARP 1

${ }^{1}$ Lancaster Environment Centre, Lancaster University, Lancaster, LA1 4YQ, UK

${ }^{2} 1$ Washington Drive, Warton, Carnforth, LA5 9RA Lancashire, UK

${ }^{3} 40$ Church Hill Avenue, Warton, Carnforth, LA5 9NU Lancashire, UK

*Corresponding Author: t.mondain-monval@lancaster.ac.uk

We would like to thank all members of the Lancaster and District Birdwatching Society who contributed sightings and Peter Cook for providing their data. Rob Robinson and Ian Hartley provided useful feedback on an earlier version of the manuscript, and Rob also advised on the statistical analyses. Thanks to the Editor, Associate Editor and anonymous reviewers whose comments helped to improve the manuscript.

This article has been accepted for publication and undergone full peer review but has not been through the copyediting, typesetting, pagination and proofreading process, which may lead to differences between this version and the Version of Record. Please cite this article as doi: 10.1111/IBI.12801

This article is protected by copyright. All rights reserved 
MR. THOMAS MONDAIN-MONVAL (Orcid ID : 0000-0002-6770-2002)

DR. STUART SHARP (Orcid ID : 0000-0002-3059-2532)

Article type : Short Communication

Editor : José Alves

Running title: Climate and demography in Sand Martins

\title{
Climatic conditions during migration affect population size and arrival dates in an Afro-Palearctic migrant
}

\author{
THOMAS O. MONDAIN-MONVAL ${ }^{1}$, KEVIN BRIGGS $^{2}$, JOHN WILSON $^{3} \&$ STUART $^{2}$
}

P. SHARP ${ }^{1}$

${ }^{1}$ Lancaster Environment Centre, Lancaster University, Lancaster, LA1 4YQ, UK

${ }^{2} 1$ Washington Drive, Warton, Carnforth, LA5 9RA Lancashire, UK

${ }^{3} 40$ Church Hill Avenue, Warton, Carnforth, LA5 9NU Lancashire, UK

*Corresponding Author: t.mondain-monval@lancaster.ac.uk

Long-distance migrants are particularly susceptible to climate change because of their multistage life-cycle but understanding how climatic conditions at each of these stages influence population dynamics remains a key challenge. Here, we use long-term data from a UK population of Sand Martins Riparia riparia, a declining Afro-Palearctic migrant, to investigate how weather on the wintering grounds and at passage sites impacts population size and arrival date. General linear models revealed that population size increased and 
arrival date advanced over the study period, and both were predicted by regional climatic variables in the previous winter and on passage. These results add to a growing body of evidence showing that population change in migrant birds is influenced by climatic conditions at all stages of the life cycle.

Key words: climate change, population dynamics, Sand Martin, Riparia riparia 
In recent decades, Afro-Palearctic migrants have experienced significant population declines (Sanderson et al. 2006, Vickery et al. 2014) and shifts in phenology (Lehikoinen et al. 2004). Climate change is thought to have played a major role in driving these trends (Both \& Visser 2001, Both et al. 2006, Sanderson et al. 2006), especially as long-distance migrants spend time in multiple regions and must cope with changing climatic conditions at each stage of their life cycle (Sillett et al. 2000, Both et al. 2009b, Jones \& Cresswell 2010). Furthermore, conditions at one stage can influence populations later in the cycle (Gill et al. 2001, Newton 2004, Alves et al. 2012), although the fitness consequences of these 'carry-over effects' may not always be straightforward (Harrison et al. 2010, Senner et al. 2015). Most studies of how the climate impacts population dynamics in European migrants have focused on weather conditions on the wintering grounds (e.g. Baillie \& Peach 1992, Robinson et al. 2008) or at various stages of spring migration through North Africa and Europe (e.g. Hüppop \& Winkel 2006, Balbontin et al. 2009). However, further research is needed to understand how conditions at different stages interact to influence breeding population sizes and the timing of migration, especially in long-term studies of local populations (Gordo et al. 2013).

The major wintering area for many Afro-Palearctic migrants is the arid Sahel in Africa (Moreau 1972, Newton 2010). Population size and survival for these species is often positively correlated with Sahelian rainfall in the previous autumn (Sanderson et al. 2006, Robinson et al. 2008, Thaxter et al. 2010, Johnston et al. 2016), as these rains flood waterways for the winter and increase food availability (Peach et al. 1991, Cowley \& Siriwardena 2005, Zwarts \& van Horssen 2009). However, evidence also suggests that climatic factors during migration influence population size (Morrison et al. 2013), and that the weather conditions at stopover sites may be more important for survival than weather at the wintering grounds (Robinson et al. 2003, Schaub et al. 2005).

The timing of arrival of migrants at their breeding grounds can have important fitness consequences (Lozano et al. 1996, Alves et al. 2012), especially as arrival and breeding may be governed by both endogenous rhythms and environmental cues, causing phenological mismatches (Both \& Visser 2001, Both et al. 2009a, Dunn \& Møller 2014). Arrival dates for many species have advanced in recent decades (Lehikoinen et al. 2004, Sparks et al. 2007), most likely because climate change has shifted the timing of bud burst and insect emergence throughout migratory flyways (Marra et al. 2005, Gordo 2007). Although migrants are unlikely to be able to reliably predict conditions at breeding sites from the weather at the 
wintering grounds, it has been suggested that large-scale climate phenomena, such as the North Atlantic Oscillation (NAO), could provide environmental links between wintering, stopover and breeding sites. In years with high winter NAO values, conditions are warmer and wetter throughout continental Europe, but drier in southern Europe, causing earlier bud burst and insect emergence (Stenseth et al. 2003). This has been shown to correlate with the advanced arrival of migrants to their breeding grounds, either due to improved foraging or because conditions during northwards migrations act as cues to those on the breeding grounds (Forchhammer et al. 2002, Both et al. 2005, Rubolini et al. 2007). Indeed, it is unlikely that individuals respond directly to NAO values or air temperatures, but rather the effects these have on the ground and on body condition.

Sand Martins Riparia riparia are Afro-Palearctic migrants and a Species of European Conservation Concern (SPEC, BirdLife International 2004). While the UK population has shown signs of a recent increase, trends differ between regions (Morrison et al. 2013) and studies of local breeding populations may offer insights into the underlying mechanisms. Population size correlates strongly with Sahelian rainfall in the previous year (Szép 1995, Wernham et al. 2002, Zwarts \& van Horssen 2009, Norman \& Peach 2013), but no studies have investigated the effect of weather conditions during migration. Similarly, while the arrival dates of Sand Martins in the UK have advanced in recent years, and this has been linked to warmer spring temperatures (Mason 1995, Sparks et al. 2007), it remains unknown whether the conditions experienced during winter and migration influence arrival dates in local breeding populations. Here, we used general linear models to analyse long-term data on population size and arrival date from Lancashire, UK. We aim to investigate (1) how weather conditions at the wintering grounds and stopover sites affect local population size and arrival dates and (2) whether these conditions interact to mediate one another.

\section{METHODS}

\section{Population size}

The number of occupied Sand Martin burrows along an approximately $33 \mathrm{~km}$ stretch of the River Lune, Lancashire, UK, was counted every year from 1974 to 2014 using methods developed by the British Trust for Ornithology (BTO) for the Waterway Bird Survey (Williamson 1974, Marchant 1978). The site ranges from Skerton Weir near Lancaster 
$\left(54.06^{\circ} \mathrm{N}, 2.79^{\circ} \mathrm{W}\right)$ to Kirkby Lonsdale $\left(54.2^{\circ} \mathrm{N}, 2.59^{\circ} \mathrm{W}\right)$, and the only year for which no data are available is 2001, when an outbreak of foot-and-mouth disease prevented access. Occupied burrows (i.e. nests) were counted in June, after most birds had started breeding but before most young had fledged, using binoculars to observe digging, repeated visits to the same burrow by adult birds and fresh droppings at burrow entrances; or by walking in front of the colony to observe birds leaving their burrows. The number of occupied burrows in each year was used as an estimate of population size; these methods have been shown to provide a reliable way of monitoring population change in this species (Norman \& Peach 2013). Long stretches of river on either side of the study site are unsuitable for Sand Martins, but nesting habitat is not limiting within the site; changes in population size are therefore unlikely to be strongly influenced by density dependent breeding dispersal.

\section{Arrival date}

The first arrival dates of Sand Martins in Lancashire between 1957 and 2014 were provided by the Lancaster and District Bird Watching Society (LDBWS), who collate local records. However, fifteen years of data were missing during this period (1958-59, 1964, 1968-71, 1988 and 1992-1998) when no sightings away from breeding colonies were reported. Many records within the dataset came from RSPB Leighton Moss, a nearby nature reserve where daily bird observations have been recorded since 1966. In order to maximise the reliability of first arrival dates in Lancashire and to avoid missing years, the entire Leighton Moss dataset (from 1966 to 2014) and the LDBWS dataset were compared to find the earliest recorded arrival date in each year. First arrival dates, hereafter 'arrival dates', were taken to be the date of the first sighting anywhere in Lancashire, with only three years when no sightings were made (1958-59 and 1964). In years where sightings from both datasets were available, they were correlated at $r=0.57$. Arrival dates are unlikely to accurately indicate the earliest arrival date of local breeders, especially as the earliest birds may not stay in Lancashire to breed but rather migrate further north (Sparks et al. 2005); observer effort may also have varied between years. Nonetheless, these sightings were considered to provide a useful index of the timing of arrival of Sand Martins in the Northwest of England.

\section{Weather}

The Sahel Rainfall Index between June and October was used as a measure of conditions in the subsequent winter. This is an index of the mean Sahelian rainfall across weather stations in the area bounded by $10^{\circ} \mathrm{N}-20^{\circ} \mathrm{N}$ and $20^{\circ} \mathrm{W}-10^{\circ} \mathrm{E}$, provided by the Joint Institute for the 
Study of the Atmosphere and Ocean (JISAO,

http://research.jisao.washington.edu/data_sets/sahel/\#analyses). The NAO Index for winter (December to March) was obtained from Hurrell (2015); this measures the difference in sea level pressure between Lisbon, Portugal, and Stykkisholmur/Reykjavik, Iceland, and is known to affect spring weather conditions in continental Europe (Hurrell 2015). Average monthly temperature and total rainfall across March and April in the area of North Africa bounded by $33^{\circ} \mathrm{N}-38^{\circ} \mathrm{N}$ and $9^{\circ} \mathrm{W}-12^{\circ} \mathrm{E}$ were obtained from the University of East Anglia Climatic Research Unit's (CRU) TS3.22 high-resolution gridded dataset (Jones \& Harris 2008). This area is an important stopover site for Sand Martins and includes most ring recovery locations in North Africa, and these months were considered most biologically meaningful for the peak of passage through the region (Wernham et al. 2002, du Feu et al. 2009). Northwest English average monthly temperature and total rainfall in April and May, obtained from the Meteorological Office regional weather datasets (http://www.metoffice.gov.uk/climate/uk/summaries/datasets), were also collated because spring weather conditions are considered important correlates of arrival date in the UK (Wernham et al. 2002). Northwest England comprises South Cumbria, all of Lancashire, Greater Manchester, Merseyside and North Cheshire.

\section{Statistical analysis}

The effects of weather conditions on the wintering grounds and stopover sites on population size over a 40-year period were analysed using general linear models. Population size was fitted as the response variable, and predictors included the following: year of survey fitted as a continuous variable, the Sahel Rainfall Index in the previous year, the NAO Index in the previous winter and the North African average temperature $\left({ }^{\circ} \mathrm{C}\right)$ and total rainfall (in $\mathrm{mm}$ ) in spring, together with the interactions between all pairs of weather variables. All two-way interactions were included because we wanted to investigate whether conditions at different stages had interdependent effects, but we had no clear predictions about which variables might be the most important (Saino \& Ambrosini 2008). Northwest English weather data were not included because population size is more dependent on winter conditions than those immediately prior to arrival (Robinson et al. 2008). Year was included to account for any inter-annual variation in population size over and above that accounted for by the weather variables and to establish any temporal trends in population size over the study period. A change in conditions over time could also affect population size but including interaction 
terms between weather variables and year over-parameterised the models and reduced explanatory power.

Collinearity between all predictors was assessed using correlation plots and Variance Inflation Factors (VIFs, following Zuur et al. 2009). North African temperature and rainfall were highly negatively correlated $(\mathrm{r}=-0.7)$. North African temperature during spring is probably more important than rainfall due to its effects on photosynthesis and insect abundance (Both et al. 2005, Sparks et al. 2007, Robinson et al. 2008), and preliminary analyses showed that rainfall explained little additional variation in population size over and above temperature; only North African temperature was therefore included in the models. All the remaining variables were likely to have independent effects in the model $(r<0.5$ and VIFs $<2$ in all cases). All variables were centred and standardised (following Schielzeth 2010) before general least squares models in the nlme package were used to account for autocorrelation in population size between years (Pinheiro et al. 2015). The AR-1 autocorrelation structure, which implements greater similarity in population size in years close together than those further apart, was fitted to the data and compared to a general linear model (GLM) without autocorrelation. The GLM had a marginally lower AICc and was chosen over the autocorrelation model. GLMs were fitted in R version 3.2.3 (R Core Team 2019) with a Gaussian error distribution and the identity link function. All possible candidate models were fitted and compared using the AICc value; those within 2 AICc units of the bestfitting model were averaged in the MuMIn package (Barton 2015). Finally, model validation was carried out for the average model in order to verify that the best-fitting models were not violating assumptions. This was done by plotting the distribution of the model's residuals, the residuals versus fitted values and the residuals versus each explanatory variable.

The analysis of arrival dates in 54 years of records followed a similar procedure to that for population size. Arrival dates were converted into Julian Dates (JD, days since $1^{\text {st }}$ January) and then fitted as the response variable in a GLM with the same explanatory variables as before, along with Northwest English temperature and rainfall (in April and May). The latter were considered likely correlates of arrival dates in Lancashire. Again, North African temperature and rainfall were highly correlated $(\mathrm{r}=-0.7)$, so rainfall was removed in subsequent analyses. Following this, the strongest correlations were found between Northwest English temperature and year, and North African temperature and year $(\mathrm{r}=0.5)$, whereas all others were weaker $(r<0.5)$ and VIFs low $(<2)$. All two-way interactions between 
weather variables were included and all variables were centred and standardised before analysis. The data were checked for autocorrelation using general least squares models as for the analysis of population size, but none was found. Therefore, GLMs were fitted with a Gaussian error distribution and identity link function, and then compared, averaged and validated using the same approach as above.

The data that support the findings of this study are available from the corresponding author upon reasonable request.

\section{RESULTS}

\section{Population size}

Population size along the River Lune showed marked fluctuations but a gradual increase over the study period (Fig. 1a). The variables Year, the Sahel Rainfall Index and North African temperature were present in the best-fitting models and were all positively correlated with population size (Table 1a, Online Supplementary Material Table S1, Fig. 1a, Fig. 2a, b). No other explanatory variables were in the top performing models.

\section{Arrival date}

The first arrival date of Sand Martins in Lancashire advanced over the study period (Fig. 1b). Arrival date was negatively correlated with year, the Sahel Rainfall Index and the NAO Index (Table 1b, Online Supplementary Material Table S2, Fig. 1a, Fig. 3a, b). Arrival date was also negatively correlated with North African temperature but positively correlated with Northwest English temperature, although the effect sizes were small (Table 1b). The effects sizes were also small for the interactions between the NAO Index and North African temperature, and between the NAO Index and Northwest English temperature (Table 1b).

\section{DISCUSSION}

The size of the River Lune Sand Martin population was positively correlated with the Sahel Rainfall Index in the previous year and North African spring temperature, even after controlling for inter-annual variation. This supports previous research showing that Sahelian 
rainfall influences population size in this and other species (Baillie \& Peach 1992, Zwarts \& van Horssen 2009, Norman \& Peach 2013), but our results suggest that conditions at stopover sites are also important. Other studies have found that weather at stopover sites is crucial for migratory species and their population size, but primarily those species wintering in Southern Africa and using the Sahel as a stopover (Ebbinge \& Spaans 1995, Newton 2006, Ockendon et al. 2014); ours demonstrates the impact of conditions in North Africa on population size in a European breeding population. For Sand Martins, like many species, crossing the Sahara Desert is very energetically costly, meaning that birds are likely to be in poor condition on arrival in North Africa (Balbontín et al. 2009). The stopover here allows migrants to increase their fat stores before continuing, but they may be particularly susceptible to changes in local weather at this time. Warmer temperatures may be important through their effect on photosynthesis and insect abundance (Berry \& Bjorkman 1980, Bale et al. 2002, Sage \& Kubien 2007) with increases in prey availability benefitting foraging efficiency and reducing competition, which may in turn improve survival during migration (Ebbinge \& Spaans 1995, Morrison et al. 2007).

The arrival date of Sand Martins in Lancashire advanced over the study period and was negatively correlated with the Sahel Rainfall Index and the NAO Index. This suggests that improved conditions during winter and on migration resulted in earlier arrival in Lancashire, perhaps because such conditions allow birds to build up fat stores and complete their winter moult more quickly (Ebbinge \& Spaans 1995, van den Brink et al. 2000). These findings contrast with those of Robson and Barriocanal (2011), who showed that favourable conditions at wintering grounds and stopover sites were associated with a delay in migration in various species. However, species respond differently to these conditions (Saino et al. 2007, Balbontín et al. 2009, Cooper et al. 2015), and some may even bypass certain stopover sites completely when the weather is favourable (Shamoun-Baranes et al. 2010).

Alternatively, good conditions may increase the intra-individual spread in arrival dates to the breeding grounds, while delaying it on average. If so, first arrival date would not be representative of the population, although first arrival date is positively correlated with mean arrival date in many species (Sparks et al. 2005).

The NAO Index was strongly inverseley correlated with arrival date, as reported in other studies (Hüppop 2003, Rubolini et al. 2007). High NAO values in winter likely increase the speed of northward migration by improving conditions throughout Europe prior to arrival 
(Stenseth et al. 2003, Rubolini et al. 2007). A high NAO also advances spring phenology, thereby facilitating an earlier start to the breeding season (Forchhammer et al. 1998, Hüppop 2003, Parmesan \& Yohe 2003, Rubolini et al. 2007).

The effect of weather conditions in winter and on migration may not influence arrival dates through their impact on body condition, but rather by providing birds with cues to conditions on the breeding grounds. Studies of other species have found individuals to be highly repeatable in their migration schedule, particularly in their pre-breeding movements (Stanley et al. 2012, Conklin et al. 2013), and individuals may use weather conditions to inform migratory timing (Both 2010, Schmaljohann et al. 2012). Correlations between weather conditions at breeding and wintering sites are likely to provide cues for migratory birds to adjust their migration schedule (Saino \& Ambrosini 2008), but their usefulness may be reduced due to the spatial variability of climate change (La Sorte et al. 2019). It is most likely that both body condition and the provision of cues influence arrival dates given that individuals may be repeatable in migration schedule but less so in the route taken, which is presumably dependent on ground conditions (Stanley et al. 2012).

It is likely that the weather variables we investigated are correlated with conditions elsewhere in the migratory flyway of Sand Martins (Saino \& Ambrosini 2008). It is therefore difficult to know whether these variables are directly affecting individuals or if the weather elsewhere is more important. Regardless, they provide a useful index of the climatic conditions which affect migratory species. This study therefore reinforces the notion that climatic factors at all stages of migration are likely to be important determinants of population change for AfroPalearctic migrants. While the interactions between the climatic variables were weak and there may not be carry-over effects between the conditions Sand Martins experience at different stages of migration, future studies of other species should also test for these effects. Understanding the influences of large-scale environmental processes and conditions on changes in local populations could provide valuable insights for migrant conservation and improve our predictions of how animal populations will respond to future climatic change.

We would like to thank all members of the Lancaster and District Birdwatching Society who contributed sightings and Peter Cook for providing their data. Rob Robinson and Ian Hartley provided useful feedback on an earlier version of the manuscript, and Rob also advised on the 
statistical analyses. Thanks to the Editor, Associate Editor and anonymous reviewers whose comments helped to improve the manuscript.

\section{REFERENCES}

Alves, J. A., Gunnarsson, T. G., Potts, P. M., Gélinaud, G., Sutherland, W. J. and Gill, J. A. (2012). Overtaking on migration: does longer distance migration always incur a penalty?, OIKOS 121(3): 464-470.

Baillie, S. R. and Peach, W. J. (1992). Population limitation in Palaearctic- African migrant passerines, Ibis 134(1): 120-132.

Balbontín, J., Møller, A. P., Hermosell, I. G., Marzal, A., Reviriego, M., and De Lope, F. (2009). Individual responses in spring arrival date to ecological conditions during winter and migration in a migratory bird, Journal of Animal Ecology 78(5): 981-989.

Bale, J. S., Masters, G. J., Hodkinson, I. D., Awmack, C., Bezemer, T. M., Brown, V. K., Butterfield, J., Buse, A., Coulson, J. C. and Farrar, J. (2002). Herbivory in global climate change research: direct effects of rising temperature on insect herbivores, Global Change Biology 8(1): 1-16.

Bartoń, K. (2015). MuMIn: Multi-model inference. R package version.

Berry, J. and Bjorkman, O. (1980). Photosynthetic response and adaptation to temperature in higher plants, Annual Review of Plant Physiology 31(1): 491-543.

BirdLife International (2004) Birds in Europe: Population Estimates, Trends and Conservation Status. Cambridge, UK. BirdLife International.

Both, C. (2010). Flexibility of timing of avin migration to climate change masked by environmental constraints en route, Current Biology 20(3): 243-248.

Both, C., Bijlsma, R. G and Visser, M. E (2005). Climatic effects on timing of spring migration and breeding in a long-distance migrant, the Pied Flycatcher Ficedula hypoleuca, Journal of Avian Biology 36(5): 368-373. 
Both, C., Bouwhuis, S., Lessells, C. and Visser M. E. (2006). Climate change and population declines in a long-distance migratory bird, Nature 441(7089): 81-83.

Both, C., Van Asch, M., Bijlsma, R. G., Van Den Burg, A. B. and Visser, M. E. (2009a). Climate change and unequal phenological changes across four trophic levels: constraints or adaptations?, Journal of Animal Ecology 78(1): 73-83.

Both, C., Van Turnhout, C. A., Bijlsma, R. G., Siepel, H., Van Strien, A. J. and Foppen, R. P. (2009b). Avian population consequences of climate change are most severe for longdistance migrants in seasonal habitats, Proceedings of the Royal Society B: Biological Sciences (DOI: 10.1098/rspb.2009.1525).

Both, C. and Visser, M. E. (2001). Adjustment to climate change is constrained by arrival date in a long-distance migrant bird, Nature 411(6835): 296-298.

Conklin, J. R., Battley, P. F. And Potter, M. A. (2013). Absolute consistency: Individual versus population variation in annual-cycle schedules of a long-distance migrant bird, PLoS One https://doi.org/10.1371/journal.pone.0054535

Cooper, N. W., Sherry, T. W. and Marra, P. P. (2015). Experimental reduction of winter food decreases body condition and delays migration in a long-distance migratory bird, Ecology 96(7): 1933-1942.

Cowley, E. and Siriwardena, G. M. (2005). Long-term variation in survival rates of Sand Martins Riparia riparia: dependence on breeding and wintering ground weather, age and sex, and their population consequences, Bird Study 52(3): 237-251.

du Feu, C. R., Joys, A. C., Clark, J. A., Fiedler, W., Downie, I. S., van Noordwijk, A. J., Spina, F., Wassenaar, R. and Baillie, S. R. (2009). "EURING Data Bank geographical index 2009." from http://www.euring.org/edb.

Dunn, P. O. and Møller, A. P. (2014). Changes in breeding phenology and population size of birds, Journal of Animal ecology 83(3): 729-739.

Ebbinge, B. S. and Spaans, B. (1995). The importance of body reserves accumulated in spring staging areas in the temperate zone for breeding in Dark-bellied Brent Geese Branta b. bernicla in the High Arctic, Journal of Avian Biology 26(2): 105-113. 
Forchhammer, M. C., Post, E. and Stenseth, N. C. (1998). Breeding phenology and climate..., Nature 391(6662): 29-30.

Forchhammer, M. C., Post, E. and Stenseth, N. C. (2002). North Atlantic Oscillation timing of long- and short-distance migration, Journal of Animal Ecology 71(6): 1002-1014.

Gill, J. A., Norris, K., Potts, P. M., Gunnarsson, T. G., Atkinson, P. W. and Sutherland, W. J. (2001). The buffer effect and large-scale population regulation in migratory birds, Nature 412: 436-438.

Gordo, O. (2007). Why are bird migration dates shifting? A review of weather and climate effects on avian migratory phenology, Climate research 35(1): 37.

Gordo, O., Tryjanowski, P., Kosicki, J. V. and Fulín, M. (2013). Complex phonological changes and their consequences in the breeding success of a migratory bird, the white stork Ciconia ciconia. Journal Animal Ecology 82(5): 1072-1086.

Harrison, X. A., Blount, J. D., Inger, R., Norris, D. R. and Bearhop, S. (2010). Carry-over effects as drivers of fitness differences in animals, Journal of Animal Ecology 80:418.

Hüppop, O. (2003). North Atlantic Oscillation and timing of spring migration in birds, Proceedings of the Royal Society of London. Series B: Biological Sciences 270(1512): 233-240.

Hüppop, O. and Winkel, W. (2006). Climate change and the timing of spring migration in the long-distance migrant Ficedula hypoleuca in central Europe: the role of spatially different temperature changes along migration routes. J. Ornith. 147(2): 344-353.

Hurrell, J. (2015). "The Climate Data Guide: Hurrell North Atlantic Oscillation (NAO) Index (station-based)." Retrieved 17/12/2015, from https://climatedataguide.ucar.edu/climate-data/hurrell-north-atlantic-oscillation-naoindex-station-based.

Johnston, A., Robinson, R. A., Gargallo, G., Julliard, R., Jeugd, H. and Baillie, S. R. (2016). Survival of Afro- Palaearctic passerine migrants in western Europe and the impacts of seasonal weather variables, Ibis 158(3): 465-480. 
Jones, T. and Cresswell, W. (2010). The phenology mismatch hypothesis: are declines of migrant birds linked to uneven global climate change?, Journal of Animal Ecology 79(1): 98-108.

Jones, P.D. and Harris, I.C. (2008). Climatic Research Unit (CRU) time-series datasets of variations in climate with variations in other phenomena. NCAS British Atmospheric Data Centre, Retrieved 19/02/2015, from http://catalogue.ceda.ac.uk/uuid/3f8944800cc48e1cbc29a5ee12d8542d.

La Sorte, F. A., Fink, D. and Johnston, A. (2019). Time of emergence of novel climates for North American migratory bird populations, Ecography, 42(6): 1079-1091.

Lehikoinen, E., Sparks, T. H. and Zalakevicius, M. (2004). Arrival and departure dates, Advances in ecological research 35: 1-31.

Lozano, G., Perreault, S. and Lemon, R. (1996). Age, arrival date and reproductive success of male American Redstarts Setophaga ruticilla, Journal of Avian Biology: 164-170.

Marchant, J. H. (1978). Bird population changes 1976-77, Bird Study 25:245-252

Marra, P. P., Francis, C. M., Mulvihill, R. S. and Moore, F. R. (2005). The influence of climate on the timing and rate of spring bird migration, Oecologia, 142(2): 307-315.

Mason, C. F. (1995). Long-term trends in the arrival dates of spring migrants, Bird Study 42(3): 182-189.

Moreau, R. E. (1972). The Palaearctic-African Bird Migration Systems. London, Academic Press.

Morrison, G. R., Davidson, N. C. and Wilson, J. R. (2007). Survival of the fattest: body stores on migration and survival in Red Knots Calidris canutus islandica, Journal of Avian Biology 38(4): 479-487.

Morrison, C. A., Robinson, R. A., Clark, J. A., Risely, K., Gill, J. A. and Duncan, R. (2013). Recent population declines in Afro-Palaearctic migratory birds: the influence of breeding and non-breeding seasons, Diversity and Distributions 19(8): 1051-1058.

Newton, I. (2004). Population limitation in migrants, Ibis 146(2): 197-226.

This article is protected by copyright. All rights reserved 
Newton, I. (2006). Can conditions experienced during migration limit the population levels of birds?, Journal of Ornithology 147(2): 146-166.

Newton, I. (2010). The migration ecology of birds, Academic Press.

Norman, D. and Peach, W. J. (2013). Density- dependent survival and recruitment in a longdistance Palaearctic migrant, the Sand Martin Riparia riparia, Ibis 155(2): 284-296.

Ockendon, N., Johnston, A. and Baillie, S. R. (2014). Rainfall on wintering grounds affects population change in many species of Afro-Palaearctic migrants, Journal of Ornithology 155(4): 905-917.

Parmesan, C. and Yohe, G. (2003). A globally coherent fingerprint of climate change impacts across natural systems, Nature 421(6918): 37-42.

Peach, W., Baillie, S. and Underhill, L. (1991). Survival of British Sedge Warblers Acrocephalus schoenobaenus in relation to west African rainfall, Ibis 133(3): 300305.

Pinheiro, J., Bates, D., DebRoy, S., Sarkar, D. and R Core Team (2018). nlme: linear and nonlinear mixed effects models. $R$ package version 3.1.R Core Team (2015). R: A language and environment for statistical computing. $R$ Foundation for Statistical Computing. Vienna, Austria.

R Core Team (2019). R: A language and environment for statistical computing. R Foundation for Statistical Computing. Vienna, Austria. https://www.R-project.org/.

Robinson, R. A., Balmer, D. E. and Marchant, J. H. (2008). Survival rates of hirundines in relation to British and African rainfall, Ringing \& Migration 24(1): 1-6.

Robinson, R. A., Crick, H. Q. and Peach, W. J. (2003). Population trends of Swallows Hirundo rustica breeding in Britain: there are regional and habitat differences, but no long-term decline in numbers, Bird Study 50(1): 1-7.

Robson, D. and Barriocanal, C. (2011). Ecological conditions in wintering and passage areas as determinants of timing of spring migration in trans- Saharan migratory birds, Journal of Animal Ecology 80(2): 320-331. 
Rubolini, D., Ambrosini, R., Caffi, M., Brichetti, P., Armiraglio, S. and Saino, N. (2007). Long-term trends in first arrival and first egg laying dates of some migrant and resident bird species in northern Italy, International journal of biometeorology 51(6): 553-563.

Saino, N. and Ambrosini, R. (2008). Climatic connectivity between Africa and Europe may serve as a basis for phenotypic adjustment of migration schedules of trans-Saharan migratory birds. Global Change Biology 14(2): 250-263.

Sage, R. F. and Kubien, D. S. (2007). The temperature response of C3 and C4 photosynthesis, Plant, Cell \& Environment 30(9): 1086-1106.

Saino, N., Rubolini, D., Jonzén, N., Ergon, T., Montemaggiori, A., Stenseth, N. C. and Spina, F. (2007). Temperature and rainfall anomalies in Africa predict timing of spring migration in trans-Saharan migratory birds, Climate Research 35(1): 123.

Sanderson, F. J., Donald, P. F., Pain, D. J., Burfield, I. J. and van Bommel, F. P. J. (2006). Long-term population declines in Afro-Palearctic migrant birds, Biological Conservation 131(1): 93-105.

Schaub, M., Kania, W. and Köppen, U. (2005). Variation of primary production during winter induces synchrony in survival rates in migratory white storks Ciconia ciconia, Journal of Animal Ecology 74(4): 656-666.

Schielzeth, H. (2010). Simple means to improve the interpretability of regression coefficients, Methods in Ecology and Evolution 1(2): 103-113.

Schmaljohann, H., Fox, J. W. and Bairlein, F. (2012). Phenotypic response to environmental cues, orientation and migration costs in songbirds flying halfway around the world, Animal Behaviour, 84(3): 623:640

Senner, N. R., Conklin, J. R. and Piersma, T. (2015). An ontogenic perspective on individual differences, Proceedings of the Royal Society B, 282: 1050.

Shamoun-Baranes, J., Leyrer, J., van Loon, E., Bocher, P., Robin, F., Meunier, F. and Piersma, T. (2010). Stochastic atmospheric assistance and the use of emergency staging sites by migrants, Proceedings of the Royal Society of London B: Biological Sciences (DOI: 10.1098/rspb.2009.2112). 
Sillett, T. S., Holmes, R. T. and Sherry, T. W. (2000). Impacts of a global climate cycle on population dynamics of a migratory songbird, Science 288(5473): 2040-2042.

Sparks, T., Bairlein, F., Bojarinova, J., Hüppop, O., Lehikoinen, E., Rainio, K., Sokolov, L. and Walker, D. (2005). Examining the total arrival distribution of migratory birds, Global Change Biology 11(1): 22-30.

Sparks, T., Huber, K., Bland, R., Crick, H., Croxton, P., Flood, J., Loxton, R., Mason, C., Newnham, J. and Tryjanowski, P. (2007). How consistent are trends in arrival (and departure) dates of migrant birds in the UK?, Journal of Ornithology 148(4): 503-511.

Stanley, C. Q., MacPherson, M., Fraser, K. C., McKinnon, E. A. And Stutchbury, B. J. M. (2012). Repeat tracking of individual songbirds reveals consistent migration timing but flexibility in route, PLoS One https://doi.org/10.1371/journal.pone.0040688

Stenseth, N. C., Ottersen, G., Hurrell, J. W., Mysterud, A., Lima, M., Chan, K. S., Yoccoz, N. G. and Ådlandsvik, B. (2003). Studying climate effects on ecology through the use of climate indices: the North Atlantic Oscillation, El Nino Southern Oscillation and beyond, Proceedings of the Royal Society of London B: Biological Sciences 270(1529): 2087-2096.

Szép, T. (1995). Survival rates of Hungarian Sand Martins and their relationship with Sahel rainfall, Journal of Applied Statistics 22(5-6): 891-904.

Thaxter, C. B., Joys, A. C., Gregory, R. D., Baillie, S. R. and Noble, D. G. (2010). Hypotheses to explain patterns of population change among breeding bird species in England, Biological Conservation 143(9): 2006-2019.

van den Brink, B., Bijlsma, R. and Van der Have, T. (2000). European Swallows Hirundo rustica in Botswana during three non-breeding seasons: the effects of rainfall on moult, Ostrich 71(1-2): 198-204.

Vickery, J. A., Ewing, S. R., Smith, K. W., Pain, D. J., Bairlein, F., Škorpilová, J. and Gregory, R. D. (2014). The decline of Afro- Palaearctic migrants and an assessment of potential causes, Ibis 156(1): 1-22. 
Wernham, C., Toms, M., Marchant, J., Clark, J., Siriwardena, G. and Bailie, S. (2002). The Migration Atlas: Movements of the Birds of Britain and Ireland. London, T \& A D Poyser.

Williamson, K. (1974). Waterways Bird Survey 1974, Cyclostyled (8 pp.). BTO, Tring.

Zuur, A., Ieno, E. N., Walker, N., Saveliev, A. A. and Smith, G. M. (2009). Mixed effects models and extensions in ecology in R. Springer Science \& Business Media, New York, NY.

Zwarts, L. and van Horssen, P. (2009). Living on the edge: wetlands and birds in a changing Sahel, KNNV Publishing Zeist. 


\section{TABLES}

Table 1. The results of the GLMs investigating (a) the effects of climatic factors on population size in Sand Martins along the River Lune, Lancashire, UK ( $n=39)$ and $(b)$ the effects of climatic factors on arrival date to Lancashire, UK ( $=53)$. Only models within 2 AICc of the best-fitting model are presented here. Values are the parameter estimates for each variable ( \pm standard error). Variable abbreviations are as follows: NAT $=$ North African temperature, SRI = Sahel Rainfall Index, NER = Northwest English rainfall, NET = Northwest English temperature, $\mathrm{AICc}=$ Aikaike Information Criterion corrected for small sample size, $\triangle \mathrm{AICc}=$ Difference in AICc between the $\mathrm{i}^{\text {th }}$ model and the best-fitting model, Weight $=$ Normalised model likelihoods .

This article is protected by copyright. All rights reserved 


\begin{tabular}{|c|c|c|c|c|c|c|c|}
\hline \multicolumn{8}{|c|}{ (a) Population size } \\
\hline Model ID & Intercept & NAT & SRI & Year & $\mathbf{R}^{2}$ & $\Delta \mathrm{AICc}$ & Weight \\
\hline \multirow[t]{2}{*}{7} & & 235.95 & 305.36 & & & & \\
\hline & 1388.15 & $(83.30)$ & $(73.74)$ & - & 0.44 & 0.00 & 0.24 \\
\hline \multirow[t]{2}{*}{15} & & 172.87 & 257.65 & 140.87 & & & \\
\hline & 1392.70 & (93.67) & $(84.8)$ & $(100.29)$ & 0.47 & 0.50 & 0.18 \\
\hline \multirow[t]{2}{*}{13} & & & 251.98 & 229.62 & & & \\
\hline & 1389.47 & - & $(87.52)$ & $(90.91)$ & 0.42 & 1.48 & 0.11 \\
\hline
\end{tabular}

\begin{tabular}{|c|c|c|c|c|c|c|c|c|c|c|c|}
\hline \multicolumn{12}{|c|}{ (b) Arrival date } \\
\hline \multirow[t]{4}{*}{ Model ID } & Intercept & NET & NAT & NAO & SRI & Year & NET & NAT $x$ & $\mathbf{R}^{2}$ & $\triangle \mathrm{AICc}$ & Weight \\
\hline & & & & & & & $\mathbf{x}$ & NAO & & & \\
\hline & & & & & & & NAO & & & & \\
\hline & & & & -4.20 & -1.65 & -4.88 & & & & & \\
\hline \multirow[t]{2}{*}{57} & 76.08 & - & - & $(0.96)$ & $(0.94)$ & $(0.97$ & - & - & 0.52 & 0.00 & 0.03 \\
\hline & & 1.07 & -1.17 & -5.23 & -1.76 & -4.21 & -2.28 & 2.59 & & & \\
\hline \multirow[t]{2}{*}{36927} & 76.49 & $(1.03)$ & $(1.01)$ & $(0.97)$ & $(0.91)$ & $(1.21)$ & $(1.00)$ & (1.11) & 0.61 & 0.26 & 0.02 \\
\hline & & & & -3.78 & & -4.76 & & & & & \\
\hline 41 & 76.13 & - & - & $(0.95)$ & - & $(0.99)$ & - & - & 0.49 & 0.81 & 0.02 \\
\hline 36911 & 76.55 & 0.75 & -1.42 & -4.76 & - & -3.83 & -2.39 & 2.42 & 0.58 & 1.55 & 0.01 \\
\hline
\end{tabular}

This article is protected by copyright. All rights reserved 


\begin{tabular}{|c|c|c|c|c|c|c|c|c|c|c|c|}
\hline & & $\begin{array}{l}(1.05) \\
\end{array}$ & $(1.03)$ & $\begin{array}{l}(0.96) \\
\end{array}$ & & $(1.23)$ & $(1.02)$ & $(1.14)$ & & & \\
\hline & & & -0.73 & -4.46 & -1.72 & -3.99 & & 1.95 & & & \\
\hline \multirow[t]{2}{*}{32829} & 76.00 & - & (1.03) & $(0.96)$ & $(0.94)$ & (1.17) & - & (1.13) & 0.55 & 1.55 & 0.01 \\
\hline & & 0.89 & & -4.70 & -1.70 & -5.38 & -1.62 & & & & \\
\hline \multirow[t]{2}{*}{4155} & 76.45 & (1.07) & - & $(0.99)$ & $(0.94)$ & (1.11) & $(1.00)$ & - & 0.55 & 1.56 & 0.01 \\
\hline & & 0.92 & & -4.35 & -1.80 & -5.36 & & & & & \\
\hline 59 & 76.11 & $(1.08)$ & - & $(0.98)$ & $(0.96)$ & (1.13) & - & - & 0.53 & 1.76 & 0.01 \\
\hline
\end{tabular}

This article is protected by copyright. All rights reserved 


\section{FIGURE LEGENDS}

Figure 1. (a) The population size of Sand Martins along the River Lune, Lancashire, UK, between 1974 and 2014 and (b) the arrival dates of Sand Martins in Lancashire, UK, between 1957 and 2014. Solid grey lines are the predicted relationships after models within 2 AICc of the best-fitting GLM were averaged, with all other variables kept at their mean value. Shaded areas show $95 \%$ confidence intervals

Figure 2. The relationships between the population size of Sand Martins along the River Lune, Lancashire, UK, and (a) the Sahel Rainfall Index during the previous winter, and (b) the NAO Index during the previous winter. Closed circles are raw data and lines show predicted relationships after models within 2 AICc of the best-fitting GLM were averaged, with all other variables kept at their mean value. Shaded areas show 95\% confidence intervals.

Figure 3. The relationships between the arrival dates of Sand Martins in Lancashire, UK, and (a) the NAO Index during the previous winter and (b) Sahel Rainfall Index in June-October the previous year. Closed circles are raw data and lines show predicted relationships after models within 2 AICc of the best-fitting GLM were averaged, with all other variables kept at their mean value. Shaded areas show $95 \%$ confidence intervals. 


\section{FIGURES}
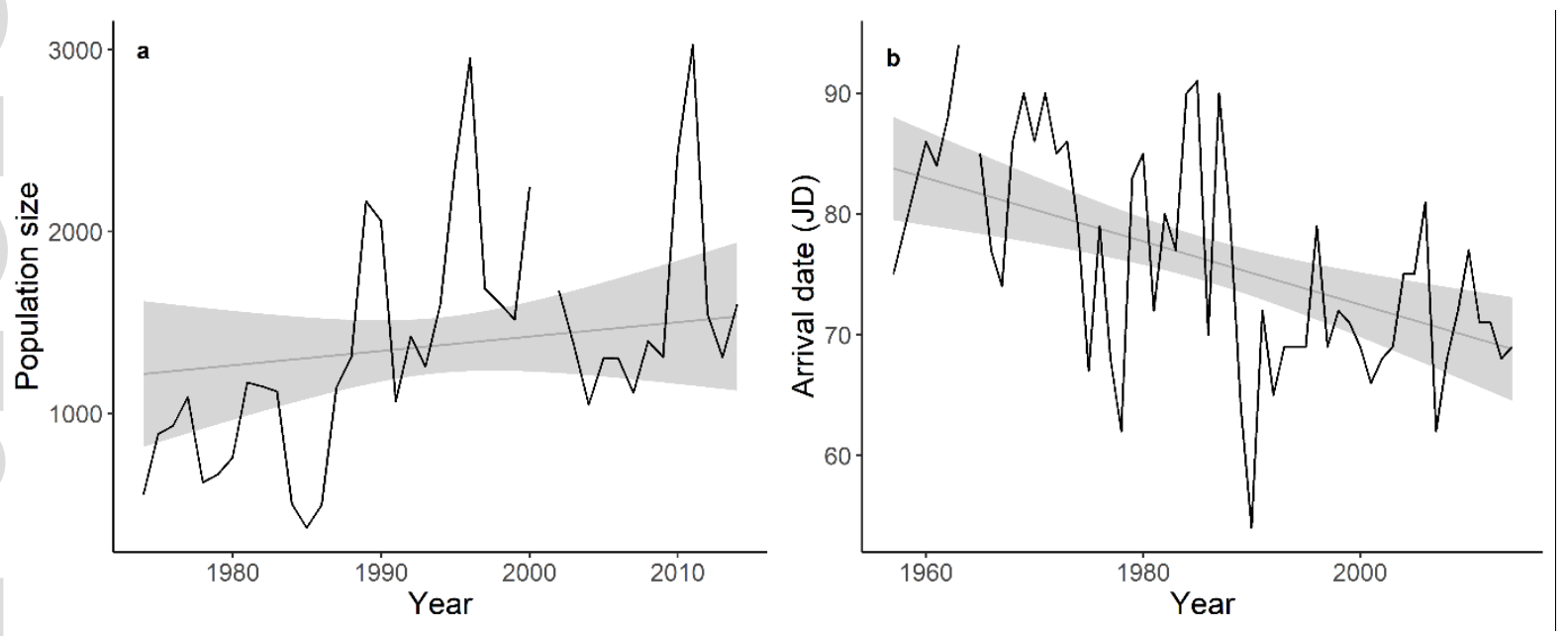

\section{Figure 1}
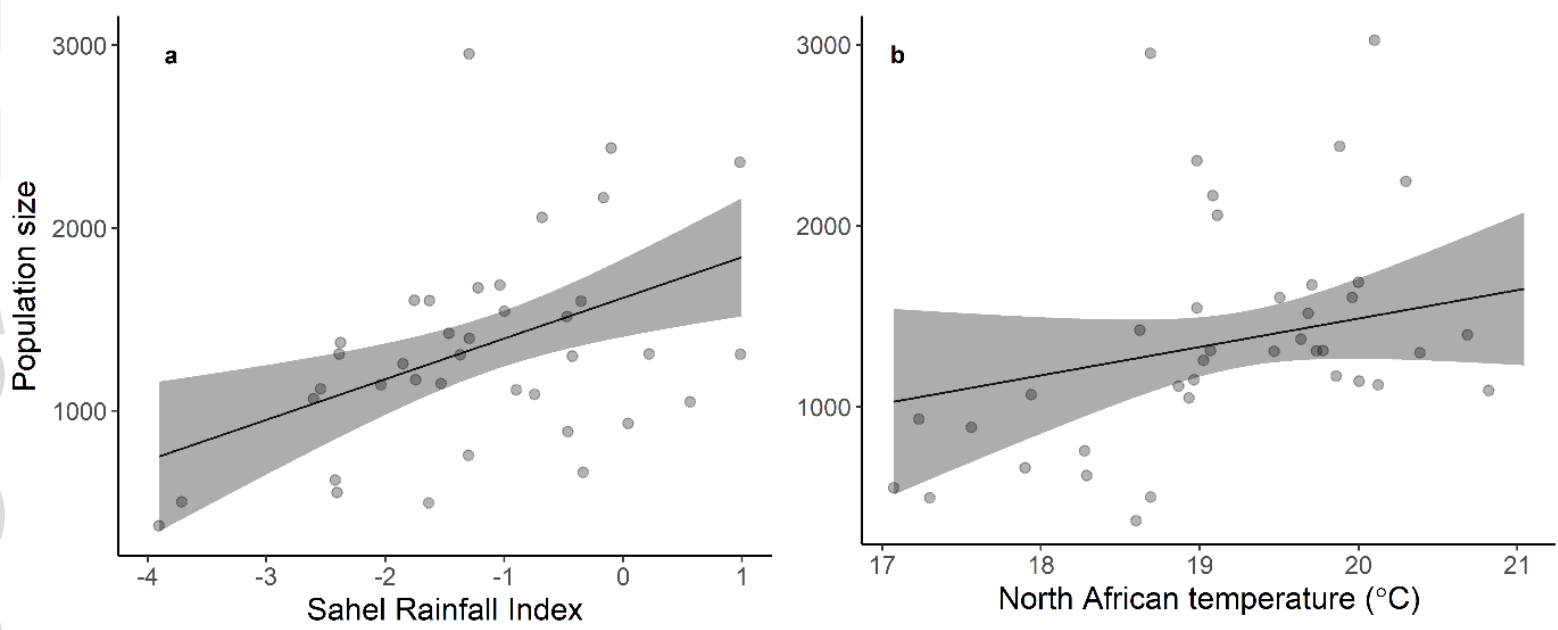

Figure 2
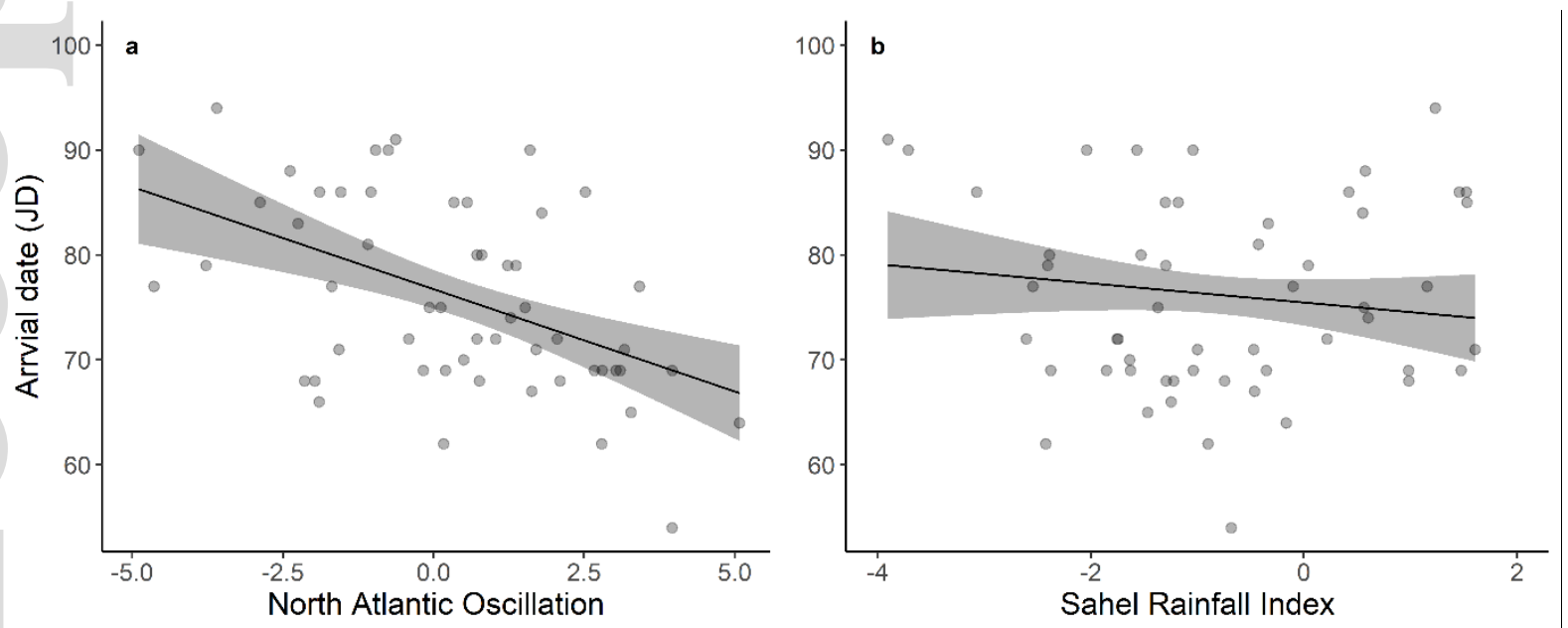

Figure 3

This article is protected by copyright. All rights reserved 


\section{APPENDICES}

Supplementary Online Material (SOM)

SOM Figure Legends

Table S1. The set of linear models (GLMs) within 5 AICc units of the best-fitting model of the correlates of the population size of Sand Martins on the River Lune, Lancashire, UK. Model averaging was carried out on the models within 2 AICc units of the best-fitting model; these are shown in bold. For the full set of GLMs contact the corresponding author. Int = Intercept, NAO = North Atlantic Oscillation Index, NAT $=$ North African temperature, SRI = Sahel Rainfall Index, yr = year, AICc = Akaikes Information Criterion corrected for small sample sizes, delta = Difference in AICc between a given model and the best-fitting model, weight $=$ The probability of any given model being the best-fitting model, the normalised relative likelihood.

Table S2. The set of general linear models (GLMs) within 5 AICc units of the best-fitting model of the correlates of the arrival dates of Sand Martins in Lancashire, UK. Model averaging was carried out on the models within 2 AICc units of the best-fitting model; these are shown in bold. For the full set of GLMs contact the corresponding author. Columns containing the two-way interactions between English Rainfall and English Temperature and English Rainfall and North African Temperature have been omitted because they appeared in none of models within 5 AICc units of the best-fitting model. Int = Intercept, NER = Northwest English rain, NET $=$ Northwest English temperature, NAT $=$ North African temperature, $\mathrm{NAO}=$ North Atlantic Oscillation Index, SRI $=$ Sahel Rainfall Index, yr $=$ Year, $\mathrm{AICc}=$ Akaikes Information Criterion corrected for small sample sizes, delta $=$ Difference in AICc between a given model and the best fitting model, weight $=$ The probability of any given model being the best-fitting model, the normalised relative likelihood.

This article is protected by copyright. All rights reserved 